\section{Is cognitive decline in the elderly associated with contextual income? Results of a population-based study in southern Brazil}

\author{
O declínio cognitivo em idosos está associado à \\ renda contextual? Resultados de um estudo de \\ base populacional no Sul do Brasil
}

\section{¿El declive cognitivo en ancianos está asociado a la renta contextual? Resultados de un estudio de base poblacional en el sur de Brasil}

\begin{abstract}
The aim of this study was to estimate the association between contextual income and cognitive decline in the elderly in Florianópolis, a mediumsized city in southern Brazil. A nested cross-sectional study was performed in a cohort of elderly $\geq 60$ years $(n=1,197)$, interviewed in the second wave (2013/2014) of the EpiFloripa cohort. Cognitive decline was assessed with the Mini Mental State Examination (MMSE) and contextual income was measured as the mean monthly income of the heads of households. Individual adjustment variables were sex, age, skin color, per capita household income, years of schooling, and time living in the neighborhood. The data were analyzed using multilevel logistic regression. The odds of cognitive decline were twice as high (OR = 1.99; 95\%CI: 1.03; 3.87) in elderly living in census tracts with the lowest income quintile compared to those in the highest quintile, independently of individual characteristics. In conclusion, the socioeconomic environment is related to cognitive decline and should be considered in public policies with a focus on health of the elderly.
\end{abstract}

Cognition Disorders; Social Class; Aged
Ana Lúcia Danielewicz 1

Katia Jakovljevic Pudla Wagner 1

Eleonora d'Orsi 1

Antonio Fernando Boing 1 


\section{Introduction}

Cognitive decline is characterized by the impairment of important skills, such as memory, attention, orientation, verbal fluency and executive functions, and often precedes a more serious diagnosis, in particular Alzheimer's disease or other dementias 1 .The preservation of cognitive ability is related to longevity and successful aging 2 , elderly people with cognitive decline are more dependent, have a higher number of comorbidities ${ }^{3}$ and a generally poor quality of life 4 .

Different prevalence of cognitive decline has been observed in studies in Europe, North America, Australia, Asia and Africa 5 with variations of between $5.1 \%$ and $35.9 \%$. In Brazil, the prevalence in six states was $25 \%$ in 2008 and 2009 , higher than that observed in other countries in Latin America and the Caribbean, such as Argentina $(8.3 \%)$ and Barbados (21.3\%) 7 .

Individual demographic and socioeconomic characteristics, such as older age, female gender and low level of education $8,9,10$ have a well-established association with cognitive decline. However, the influence of environmental socioeconomic factors on cognitive loss among the elderly population has not been so thoroughly investigated.

Studies carried out in Asia 11, North America 12 and Europe 13 have found that elderly people who lived in neighborhoods with worse socioeconomic indicators, such as lower income or education level and higher unemployment, had lower cognitive performance scores regardless of individual socioeconomic factors.

It is believed that elderly people who live in places with better socioeconomic conditions are likely to benefit more from physical, social and leisure activities available in these environments, which contributes to better cognitive function 14 . In addition, poorer neighborhoods may suffer more from the effects of crime, causing the elderly population to be socially and psychologically isolated within their community 15 .

It is also suggested that income assessed on a contextual level is directly related to the concepts of social capital and cohesion, which include the ways in which society is organized, through the establishment of norms of reciprocity and trust that help the formation of social ties and determine health at the individual level 16,17.

In addition, a systematic review 18 showed that the level of economic deprivation in the neighborhood, represented among other variables by contextual average income, is one of the main factors that affect the characteristics of the physical and social environments which can affect cognitive ability.
In Brazil, some studies that used the income variable to characterize the context have shown that lower average income and greater concentration of wealth in the neighborhood are associated with some health outcomes such as poor health self-assessment 19 , greater prevalence of functional disabilities 20 , and higher systolic blood pressure 21. However, as of September 2015, no study published in Brazil has been found with the aim of investigating the association between income and contextual cognitive decline. Because it is a country with wide socioeconomic disparities and a growing elderly population, further studies of this relationship are deemed important.

In addition, within public health policies there is evidence of a growing interest in studies to assess environmental features aimed at formulating strategies for prevention and/or intervention, with a focus on the entire community and not just specific individuals or groups. In this context, the aim of this study was to estimate the association between area level income of neighborhoods and cognitive decline among the elderly in the city of Florianópolis, Santa Catarina State, Brazil.

\section{Methods}

\section{Study area and population}

The research involved a cross-sectional study nested in a cohort of elderly residents in Florianópolis, the capital city of the state of Santa Catarina (EpiFloripa elderly study), located in southern Brazil. The data from this study were collected in 2013/2014, and the baseline study is from $2009 / 2010$. The population of the city in 2010 was 421,000 , of whom $11.4 \%$ were elderly (60 years or older), and of these, $14 \%$ were considered very elderly (80 years or older) 22 . In addition, Florianópolis is the Brazilian state capital with the highest level of quality of life according to United Nations indicators 23.

\section{Data source and sampling design}

The sample consisted of elderly men and women, aged 60 or older, who were non-institutionalized and residents of the urban area of Florianópolis at the time of the baseline study.

The cohort study sample at baseline was 1,705 elderly people, and details of the sampling procedures have been described elsewhere 24,25 . For the second wave of the cohort, 217 people who had died were excluded, resulting in 1,488 eligible participants. Refusals were considered 
when the elderly person refused to participate in the study, and losses included all interviews for which the elderly person could not be located via telephone or after four home visits (including in the evenings and at the weekend).

Data collection was performed using netbooks to apply a standardized questionnaire that had been pre-tested in a pilot study. Face-to-face interviews were conducted at home between November 2013 and November 2014. Quality control of the data was performed with a random sample of approximately $10 \%$ of the elderly people. The selected respondents were contacted by telephone and answered a short questionnaire consisting of ten questions. The kappa calculation indicated moderate to very good agreement, with values ranging from 0.51 to 0.94 .

\section{Study variables}

The outcome variable was cognitive decline, assessed using the Mini Mental State Examination (MMSE) 26. The MMSE is a neuropsychological cognitive assessment test that takes into account different cognitive domains such as temporal and spatial orientation, short-term memory, calculation, comprehension and writing. The score can range from 0 to 30 points, and in this study the cutoff points proposed by Almeida 27 were used, that probable cognitive decline is indicated by a score of below 19 points for those who are illiterate, and below 24 points for those with some education. For data analysis, the elderly were classified into two categories according to the presence or absence of cognitive decline.

The independent contextual variable was the average monthly income of the head of each household in each of the 83 census tracts included in this study, according to the Brazilian Census of $2010^{28}$, categorized into quintiles. Individual explanatory variables were sex, age (60-69 years, 70-79 years and 80 or over), self-reported skin color (white, light-skinned black, and dark; yellow $(n=6)$ and indigenous $(n=4)$ were excluded due to the small sample size), average equalized household income (divided into tertiles), and years of schooling (0-4 years, 5-8 years, 9-11 years, 12 or more years). Finally, the length of residence in the neighborhood (1-4 years, 5-9 years, 10 years or more) was also included as an explanatory variable.

\section{Data analysis}

First, descriptive analyses of the sample distribution were conducted and the prevalence and respective confidence intervals $(95 \% \mathrm{CI})$ related to cognitive decline were calculated for each in- dividual and contextual variable. After that, the nonparametric Kruskal-Wallis test was used to assess the mean difference in MMSE score according to contextual variables. A multilevel logistic regression was performed to estimate the odds ratio (OR) and 95\%CI between the outcome and the independent variable, considering the individual variables as the first level of analysis and the contextual variable as the second level.

The empty model (without covariates) was tested to estimate the total variance proportion of the outcome attributed to differences between census tracts. The other variables were then included by a forward selection method according to three models: model 1 (only contextual income); model 2 (individual variables including sex, age and skin color) and model 3 (included individual income and education variables, and the length of residence in the neighborhood).

All analyses were performed using Stata, version 13.0 (StataCorp LP, College Station, USA). P-values $<0.05$ were considered statistically significant.

\section{Ethical aspects}

The Ethics Committee for Research with Human Beings of the Federal University of Santa Catarina approved the study, case number 352/2008 at baseline 2009/2010, and Certificate of Presentation for Ethical Consideration number 16731313.0.0000.0121 in the $2013 / 2014$ wave. The participants received guidance on the research objectives and signed an informed consent form. For the elderly people who were unable to sign the informed consent form, a legal guardian was asked to do so.

\section{Results}

The final sample of those who were effectively interviewed consisted of 1,197 elderly people, representing a response rate of $80.4 \%$. Of these, 1,184 answered the MMSE and were included in the present analytic sample. The average age was 73.9 years (standard deviation 7.2 years), with a higher proportion of women (65\%) and people who reported white skin color (86.7\%). The average monthly income of the heads of the households in the census tracts was BRL 2,215.68 (interquartile range BRL 1,967.08), ranging from BRL 753.83 to BRL 10,311.25.

Cognitive decline was observed in $26.1 \%$ of the elderly people, and was more common among women (28.9\%), blacks (35.4\%), people aged 80 years or over $(44.8 \%)$, those with less than five years of schooling (45.9\%) and those 
in the lowest tertile of average equalized income (42.4\%). In addition, the prevalence of cognitive decline was higher among lower-income census tracts, being three times higher in the poorest quintile than in the richest (Table 1). The median MMSE score according to the quintiles of household income in the census tracts ranged from 24 (lowest quintile) to 28 (highest quintile), pvalue $<0.01$ (Figure 1).
Table 2 shows the results of multilevel logistic regression. Variance was observed between groups of $13 \%$ in the empty model, a value that changed to $7.8 \%$ in the model adjusted for average income for the census tracts, indicating that this contextual variable explained $40 \%$ of the variance of the second level. In the crude analysis (model 1), all categories of area-level income were inversely associated with cognitive decline. After

Table 1

Individual and contextual level characteristics of the sample of elderly people. Florianópolis, Santa Catarina State, Brazil 2013-2014.

\begin{tabular}{|c|c|c|}
\hline Characteristics & n (\%) & Cognitive decline $[\%(95 \% \mathrm{Cl})]$ \\
\hline \multicolumn{3}{|l|}{ Individual level } \\
\hline \multicolumn{3}{|l|}{ Age (years) } \\
\hline $60-69$ & $412(34.4)$ & $15.1(11.9 ; 18.9)$ \\
\hline 70-79 & $509(42.5)$ & $25.1(21.5 ; 29.1)$ \\
\hline$\geq 80$ & $276(23.1)$ & $44.8(38.9 ; 50.8)$ \\
\hline \multicolumn{3}{|l|}{ Gender } \\
\hline Male & $419(35.0)$ & $20.9(17.2 ; 25.0)$ \\
\hline Female & $778(65.0)$ & $28.9(25.8 ; 32.2)$ \\
\hline \multicolumn{3}{|l|}{ Skin color } \\
\hline White & $980(86.7)$ & $20.0(17.6 ; 22.6)$ \\
\hline Light-skinned black & $100(8.9)$ & $46.0(36.3 ; 56.0)$ \\
\hline Dark & $50(4.4)$ & $35.4(22.9 ; 50.3)$ \\
\hline \multicolumn{3}{|c|}{ Education (years of schooling) } \\
\hline$\geq 12$ & $287(24.0)$ & $7.0(4.5 ; 10.7)$ \\
\hline $9-11$ & $181(15.1)$ & $7.8(4.6 ; 12.8)$ \\
\hline $5-8$ & $199(16.6)$ & $17.7(12.9 ; 23.7)$ \\
\hline $0-4$ & $530(44.3)$ & $45.9(41.6 ; 50.2)$ \\
\hline \multicolumn{3}{|c|}{ Equalized household income (tertiles) } \\
\hline 3 & $396(32.9)$ & $10.2(7.6 ; 13.7)$ \\
\hline 2 & $402(33.6)$ & $25.4(21.3 ; 29.9)$ \\
\hline 1 & $401(33.5)$ & $42.4(37.6 ; 47.4)$ \\
\hline \multicolumn{3}{|c|}{ Length of residence in the neighborhood (years) } \\
\hline$\geq 10$ & $1,003(83.8)$ & $25.9(0.23 ; 0.29)$ \\
\hline $5-9$ & $105(8.8)$ & $21.1(0.14 ; 0.30)$ \\
\hline $1-4$ & $89(7.4)$ & $33.7(0.24 ; 0.44)$ \\
\hline \multicolumn{3}{|c|}{ Contextual level (census tracts, $n=83$ ) } \\
\hline \multicolumn{3}{|c|}{ Area-level income (quintiles) } \\
\hline 5 & $235(19.7)$ & $13.0(9.2 ; 18.1)$ \\
\hline 4 & $260(21.7)$ & $24.2(19.3 ; 29.9)$ \\
\hline 3 & $214(17.9)$ & $25.4(20.0 ; 31.8)$ \\
\hline 2 & $264(21.2)$ & $30.1(24.7 ; 36.0)$ \\
\hline 1 & $234(19.6)$ & $37.2(31.2 ; 43.6)$ \\
\hline
\end{tabular}

95\% Cl: 95\% confidence interval. 
Box-plot graph of Mini Mental State Examination (MMSE) scores by quintiles of area-level income $(p<0,01)$. Florianópolis, Santa Catarina State, Brazil, 2013-2014.

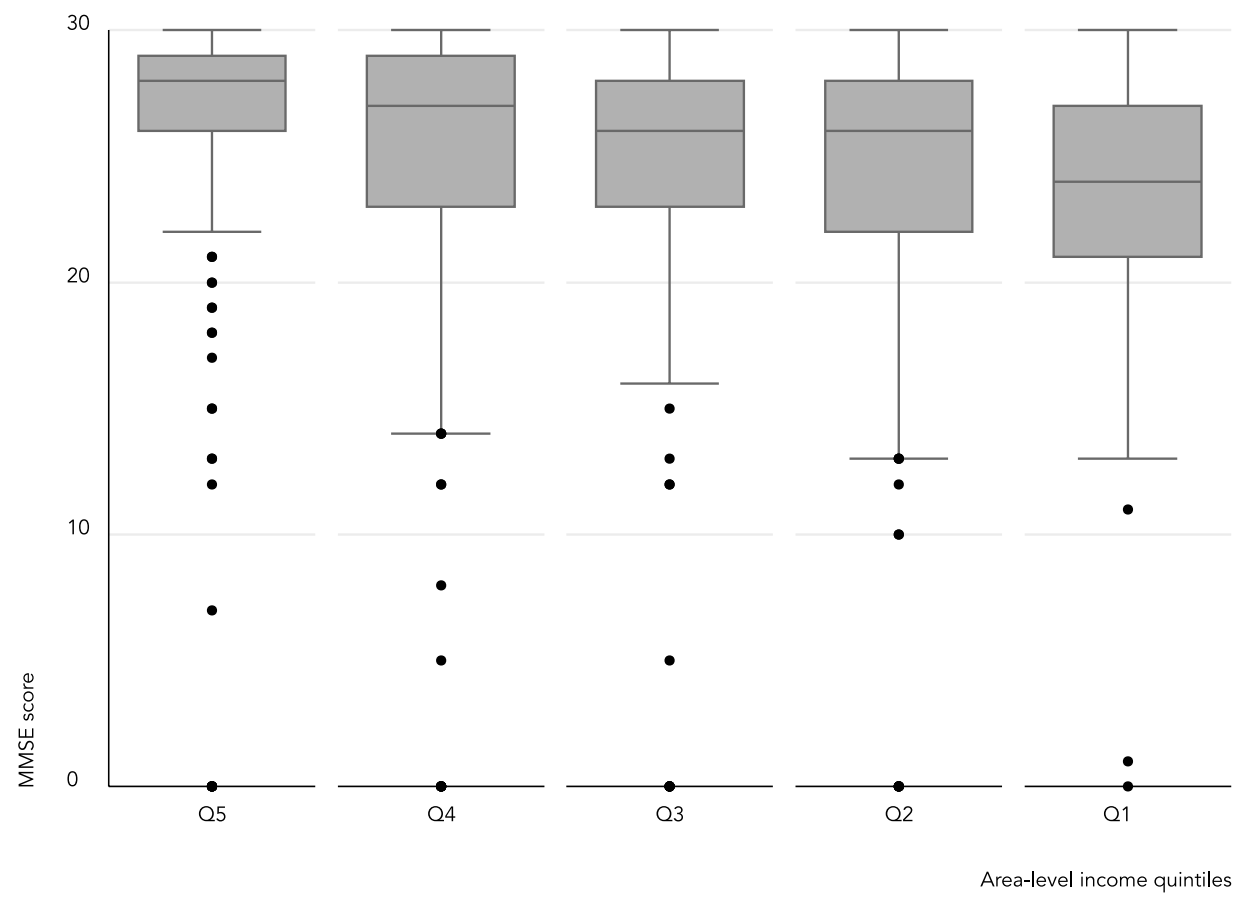

adjusting for all the individual variables (model 3) the same negative gradient associated with the outcome remained, but only the difference between the extreme quintiles was statistically significant. The odds of cognitive decline were approximately two times higher among residents of lower-income census tracts, regardless of age, gender, skin color, education, individual income or length of residence in the neighborhood.

\section{Discussion}

The main results indicated that cognitive decline is inversely related to the socioeconomic status of the neighborhood, and it is twice as likely to occur in elderly people living in the poorest areas compared to the richest, regardless of individual demographic and socioeconomic characteristics.

Similar results were observed in population studies of the elderly in Asia ( $>60$ years) 11, of British adults and elderly ( $>50$ years) 13 and of the American elderly ( $>65$ years) 12 , in which neigh- borhoods with low income and educational levels, higher unemployment and sources of public assistance were associated with cognitive decline. Similarly, institutionalized elderly people in Britain (> 65 years) living in neighborhoods with a higher deprivation index were twice as likely to experience cognitive decline compared to areas with less deprivation, regardless of individual education or social class 29 .

Only two studies with similar objectives to this one have been carried out among older adults in Latin America (both Mexican) 30,31. Sheffield \& Peek 31 observed that socioeconomic disadvantage assessed by lower income neighborhoods was associated with a higher incidence of cognitive decline over a period of five years, whereas there was no association for social disadvantage, represented by low educational levels and lower occupational classes. The study by $\mathrm{Al}$ Hazzouri et al. 30 also found that lower neighborhood socioeconomic status was significantly associated with a higher prevalence of cognitive decline, even after adjusting for individual schooling. These findings demonstrate that the 
Multivariate models of multilevel logistic regression for cognitive decline in the sample of elderly people. Florianópolis, Santa Catarina State, Brazil, 2013-2014.

\begin{tabular}{|c|c|c|c|c|}
\hline Variables & $\begin{array}{l}\text { Empty model } \\
\text { [OR }(95 \% \mathrm{CI})]\end{array}$ & $\begin{array}{c}\text { Model } 1 \\
{[\text { OR }(95 \% \mathrm{Cl})]}\end{array}$ & $\begin{array}{c}\text { Model } 2 \\
{[\text { OR }(95 \% \mathrm{Cl})]}\end{array}$ & $\begin{array}{c}\text { Model } 3 \\
\text { [OR }(95 \% \mathrm{CI})]\end{array}$ \\
\hline \multicolumn{5}{|l|}{ Fixed effects } \\
\hline Intercept & $0.31(0.25 ; 0.38)$ & $0.14(0.08 ; 0.22)$ & $0.02(0.01 ; 0.04)$ & $0.01(0.00 ; 0.02)$ \\
\hline \multicolumn{5}{|c|}{ Contextual level (census tracts, $\mathrm{n}=83$ ) } \\
\hline \multicolumn{5}{|c|}{ Area-level income (quintiles) } \\
\hline 5 & & 1.00 & 1.00 & 1.00 \\
\hline 4 & & $2.11(1.14 ; 3.92)$ * & $2.71(1.28 ; 5.75)$ * & $1.41(0.72 ; 2.75)$ \\
\hline 3 & & $2.29(1.21 ; 4.33)$ * & $2.97(1.37 ; 6.45)$ * & $1.61(0.81 ; 3.19)$ \\
\hline 2 & & $2.98(1.63 ; 5.47)$ * & $4.91(2.34 ; 10.3)$ * & $1.69(0.87 ; 3.29)$ \\
\hline 1 & & $3.97(2.17 ; 7.26)$ * & $6.77(3.24 ; 14.1) *$ & $1.99(1.03 ; 3.87)$ * \\
\hline \multicolumn{5}{|l|}{ Individual level } \\
\hline \multicolumn{5}{|l|}{ Age (years) } \\
\hline $60-69$ & & & 1.00 & 1.00 \\
\hline $70-79$ & & & $2.19(1.49 ; 3.22) *$ & $1.65(1.10 ; 2.47)$ * \\
\hline$\geq 80$ & & & $4.80(3.08 ; 7.49)$ * & $3.15(1.99 ; 5.00)$ * \\
\hline \multicolumn{5}{|l|}{ Gender } \\
\hline Male & & & 1.00 & 1.00 \\
\hline Female & & & $1.82(1.29 ; 2.58)$ * & $1.44(1.00 ; 2.08)$ * \\
\hline \multicolumn{5}{|l|}{ Skin color } \\
\hline White & & & 1.00 & 1.00 \\
\hline Light-skinned black & & & $3.34(2.06 ; 5.43)$ * & $3.01(1.84 ; 4.94)$ * \\
\hline Dark & & & $1.75(0.86 ; 3.56)$ & $1.93(0.93 ; 4.00)$ \\
\hline \multicolumn{5}{|c|}{ Education (years of schooling) } \\
\hline$\geq 12$ & & & & 1.00 \\
\hline $9-11$ & & & & $1.39(0.57 ; 3.41)$ \\
\hline $5-8$ & & & & $2.67(1.20 ; 5.96)$ * \\
\hline $0-4$ & & & & $9.07(4.36 ; 18.86)$ * \\
\hline \multicolumn{5}{|c|}{ Equalized household income (tertiles) } \\
\hline 3 & & & & 1.00 \\
\hline 2 & & & & $1.31(0.78 ; 2.20)$ \\
\hline 1 & & & & $2.27(1.36 ; 3.77)$ * \\
\hline \multicolumn{5}{|c|}{ Length of residence in the neighborhood (years) } \\
\hline$\geq 10$ & & & & 1.00 \\
\hline $5-9$ & & & & $0.86(0.44 ; 1.70)$ \\
\hline $1-4$ & & & & $1.55(0.82 ; 2.92)$ \\
\hline \multicolumn{5}{|l|}{ Random effects } \\
\hline Level-two variance (SE) & $0.49(0.15)$ & $0.28(0.11)$ & $0.40(0.16)$ & $0.05(0.09)$ \\
\hline ICC (\%) & 13.0 & 7.8 & 10.9 & 1.4 \\
\hline
\end{tabular}

95\% Cl: 95\% confidence interval; ICC: intraclass correlation coefficient; OR: odds ratio; SE: standard error.

* p-value $<0.05$.

contextual income should be considered an important feature associated with cognitive ability, especially among the elderly people in low and middle-income countries.

The relationship between socioeconomic environment and cognitive decline may be attributed to a number of issues, including access to health services, areas for leisure and social activities, psychological and lifestyle factors 31 . In particular, the elderly are more susceptible to exposure to the environment in which they live because they usually spend more time in their communities and enjoy fewer services outside the area compared to younger people 32 . 
Areas with higher deprivation may offer its residents fewer opportunities for social and cultural interaction, important factors for cognitive stimulation 33 . On the other hand, more affluent neighborhoods are more likely to provide a healthier lifestyle, as they are generally more carefully constructed environments, with spaces dedicated to leisure and physical activity that help preserve the cognitive reserves, memory and executive functions of the brain 34,35 . In addition, these places provide better access to the internet, cinemas, bookstores, libraries, museums and theaters, which are related to the maintenance of cognitive abilities 36 .

It has been suggested that social isolation is one of the factors that explains the relationship between lower socioeconomic status and cognitive decline among the elderly, since poorer neighborhoods tend to have higher rates of violence, vandalism and crime, which can make the elderly feel insecure about leaving their homes and cause them to have relations only with friends or relatives who live closer to their community 15,37 . The insecurity experienced by older people can have other implications, such as decreased levels of physical or leisure activity, loss of functional independence and the presence of symptoms of depression 38,39 , which are considered to be factors associated with cognitive decline.

Despite the evidence, the lack of studies related to the influence of contextual socioeconomic status on cognitive health among the elderly in Latin America does not allow for direct comparisons between economically similar areas. Many Brazilian cities have good quality of life indicators 23 , however the country is marked by socioeconomic inequalities, and certainly the population with lower incomes are more vulnerable to the negative effects that this has on health. Thus, environmental characteristics should be considered important factors for the planning of public health interventions.

Currently, some national programs have been implemented with a focus on promoting territorial health, such as increased access to physical activity and healthy foods, violence prevention, and stimulating sustainable development 40 . However, it is necessary to make improvements and advances in inter-sectoral health actions that facilitate the construction of healthy urban spaces, reducing social inequality, offering more opportunities to people on low incomes, as well as the inclusion of special groups such as the elderly 41 .

There are some limitations to this study that should be considered when interpreting the results. The MMSE is a validated questionnaire widely used in studies of elderly Brazilians, although its cut-off point has not yet been standardized in the literature. The choice in this study of the point proposed by Almeida 27 for the classification of cognitive decline may have influenced the results, since the largest proportion of the sample was classified as having a low education level (0-4 years), and this proposes only different points among illiterate and educated elderly.

However, sensitivity analyses were carried out related to the cut-off point used in this study, comparing it with that suggested by Brucki et al. ${ }^{42}$, Lourenço \& Veras 43 and Bertolucci et al. 44. High values were verified for the first two $(99.7 \%$ and $97.7 \%$, respectively), and only the comparison with Bertolucci et al. 44 showed low sensitivity (33.3\%), which is probably due to the greater difference of scores to detect cognitive decline in illiterate elderly people between the two points analyzed. The specificity analyses showed acceptable values when comparing with all the points analyzed; $69.8 \%$ for Brucki et al. ${ }^{42}$, 90.3\% for Lourenço \& Veras 43 and $93.1 \%$ forBertolucci et al. ${ }^{44}$.

Although the analyses were adjusted for the time of residence in the neighborhood, the characterization of the neighborhood was based on the territorial unit for the collection of census data, which may not reflect the actual area of social and economic residence for many respondents. This limitation has been observed in multilevel epidemiological studies, largely due to the availability of data provided by national surveys, which often do not represent the ideal area for investigating health outcomes 45 . The definition of a neighborhood, its spatial delimitation and the choice of variables that best relate to the outcome, make use of fairly challenging contextual measures for observational studies, and should therefore be considered with caution in their analysis 46 .

The use of secondary data collected for the 2010 Brazilian Census limited any further analysis with other variables of the socioeconomic context that could be related to cognitive decline. As an example, one can cite the average education level of the sector, which has been widely included in the contextual socioeconomic indices of similar studies, but which was not collected in the 2010 Census. However, it is worth noting that the use of a single variable that represents the analytical context may be an option to avoid the bias which could result from the use of composite indices, such as masking the variation between two areas which have the same final score, and the inability to demonstrate which of the variables have a greater effect on the outcome 47 . 
The cross-sectional design can also be considered a limitation because of the possible bias of reverse causality. Individuals with cognitive decline are more likely to reside in areas with higher socioeconomic deprivation, due to difficulties in sustaining their capacity to work. On the other hand, it was observed that it is during adulthood that most people become fixed residents and choose where they will live in old age 18 .

However, some relevant points are worth highlighting. This is a pioneering study in Brazil, which evaluated the contextual income and its relation to cognitive decline in the elderly. Moreover, among the variables investigated, sta- tistically significant differences were not found between the loss group and respondents in the second wave of the study compared to the baseline, except for the age variable $(p<0.001)$, which showed greater loss in the group aged 80 years or over, justified by the higher number of deaths in this category.

It is clear from these results that further studies are needed to investigate the relationship as well as the long-term influence of the social and economic contexts on the health of elderly Brazilians, because the country is undergoing an accelerated aging process and this elderly population should be considered a priority in strategies focusing on health promotion and quality of life.

\section{Contributors}

A. L. Danielewicz contributed to the study design and planning, data analysis and interpretation, writing, critical review, and approval of the final version. K. J. P. Wagner contributed to the study design and planning, data analysis and interpretation, critical review, and approval of the final version. E. d'Orsi contributed to the critical review and approval of the final version. A. F. Boing contributed to the study design and planning, critical review, and approval of the final version.

\section{Acknowledgments}

We thank the Brazilian Institute of Geography and Statistics (IBGE) for providing the income data for the municipality of Florianópolis. We would like to thank the EpiFloripa study participants and Brazilian National Research Council - CNPq (process 569834/2008-2) for financing the project. A. L. Danielewicz and K. J. P. Wagner received doctoral scholarships from the Brazilian Graduate Studies Coordinating Board (Capes). 


\section{References}

1. Alzheimer's Association; Centers for Disease Control and Prevention. The Healthy Brain Initiative: the public health road map for state and national partnerships, 2013-2018. Chicago: Alzheimer's Association; 2013.

2. Depp C, Vahia IV, Jeste D. Successful aging: focus on cognitive and emotional health. Annu Rev Clin Psychol 2010; 6:527-50.

3. Silva HS, Duarte YAO, Andrade FB, Cerqueira ATAR, Santos JLF, Lebrão ML. Correlates of above-average cognitive performance among older adults: the SABE study. Cad Saúde Pública 2014; 30 : 1977-86.

4. Beckert M, Irigaray TQ, Trentini CM. Quality of life, cognition and performance of executive functions in the elderly. Estud Psicol (Campinas) 2012; 29:155-62.

5. Ward A, Arrighi HM, Michels S, Cedarbaum JM. Mild cognitive impairment: disparity of incidence and prevalence estimates. Alzheimers Dement 2012; 8:14-21.

6. Neri AL, Yassuda MS, Araújo LF, Eulálio MC, Cabral BE, Siqueira MEC, et al. Metodologia e perfil sociodemográfico, cognitivo e de fragilidade de idosos comunitários de sete cidades brasileiras: Estudo FIBRA. Cad Saúde Pública 2013; 29:778-92.

7. Ashby-Mitchell K, Jagger C, Fouweather T, Anstey KJ. Life expectancy with and without cognitive impairment in seven Latin American and Caribbean countries. PLoS One 2015; 10:e0121867.

8. Miranda LP, Silveira MF, Oliveira TL, Alves SF, Junior HM, Batista AU, et al. Cognitive impairment, the Mini-Mental State Examination and socio-demographic and dental variables in the elderly in Brazil. Gerodontology 2012; 29:e34-40.

9. Ferreira PCS, Tavares DMS, Rodrigues RAP. Características sociodemográficas, capacidade funcional e morbidades entre idosos com e sem declínio cognitivo. Acta Paul Enferm 2011; 24:29-35.

10. Machado JC, Ribeiro RCL, Leal PFG, Cotta RMM. Evaluation of cognitive decline and its relationship with socioeconomic characteristics of the elderly in Viçosa, Minas Gerais. Rev Bras Epidemiol 2007; 10:592-605.

11. Wee LE, Yeo WX, Yang GR, Hannan N, Lim K, Chua $\mathrm{C}$, et al. Individual and area level socioeconomic status and its association with cognitive function and cognitive impairment (low MMSE) among community-dwelling elderly in Singapore. Dement Geriatr Cogn Disord Extra 2012; 2:529-42.

12. Shih RA, Ghosh-Dastidar B, Margolis KL, Slaughter ME, Jewell A, Bird CE, et al. Neighborhood socioeconomic status and cognitive function in women. Am J Public Health 2011; 101:1721-8.

13. Lang IA, Llewellyn DJ, Langa KM, Wallace RB, Huppert FA, Melzer D. Neighborhood deprivation, individual socioeconomic status, and cognitive function in older people: analyses from the English Longitudinal Study of Ageing. J Am Geriatr Soc 2008; 56:191-8.
14. Clarke PJ, Ailshire JA, House JS, Morenoff JD, King K, Melendez R, et al. Cognitive function in the community setting: the neighbourhood as a source of 'cognitive reserve'? J Epidemiol Community Health $2011 ; 66: 730-6$.

15. Aneshensel CS, Ko MJ, Chodosh J, Wight RG. The urban neighborhood and cognitive functioning in late middle age. J Health Soc Behav 2011; 52: 163-79.

16. Kawachi I, Berkman LF. Social cohesion, social capital, and health. In: Berkman LF, Kawachi I, editors. Social epidemiology. New York: Oxford University Press; 2000. p. 174-90.

17. Fone D, Dunstan F, Lloyd K, Williams G, Watkins J, Palmer S. Does social cohesion modify the association between area income deprivation and mental health? A multilevel analysis. Int J Epidemiol 2007; 36:338-45.

18. Wu Y-T, Prina AM, Brayne C. The association between community environment and cognitive function: a systematic review. Soc Psychiatry Psychiatr Epidemiol 2014; 50:351-62.

19. Santos SM, Chor D, Werneck GL, Coutinho ESF. Associação entre fatores contextuais e autoavaliação de saúde: uma revisão sistemática de estudos multinível. Cad Saúde Pública 2007; 23:2533-54.

20. Alves LC, Leite IC, Machado CJ. Fatores associados à incapacidade funcional dos idosos no Brasil: análise multinível. Rev Saúde Pública 2010; 44:468-78.

21. Höfelmann DA, Antunes JLF, Silva DAS, Peres MA. Is income area level associated with blood pressure in adults regardless of individual-level characteristics? A multilevel approach. Health Place 2012; 18:971-7.

22. Instituto Brasileiro de Geografia e Estatística. Sinopse do Censo Demográfico - 2010. Rio de Janeiro: Instituto Brasileiro de Geografia e Estatística; 2011.

23. Programa das Nações Unidas para o Desenvolvimento. Atlas do desenvolvimento humano no Brasil. Brasília: Programa das Nações Unidas para o Desenvolvimento; 2003.

24. Antes DL, Ribeiro DF, Schneider IJC, Benedetti TRB, d'Orsi E. Socioeconomic profile of the elderly in Florianópolis: comparative analysis studies Perfil do Idoso 2002 and EpiFloripa Idoso 2009. Rev Bras Epidemiol 2014; 17:189-202.

25. Giehl MWC, Schneider IJC, Corseuil HX, Benedetti TRB, d'Orsi E. Atividade física e percepção do ambiente em idosos: estudo populacional em Florianópolis. Rev Saúde Pública 2012; 46:516-25.

26. Folstein MF, Folstein SE, McHugh PR. "Mini-mental state": a practical method for grading the cognitive state of patients for the clinician. J Psychiatr Res 1975; 12:189-98.

27. Almeida OP. Mini exame do estado mental e o diagnóstico de demência no Brasil. Arq Neuropsiquiatr 1998; 56:605-12.

28. Instituto Brasileiro de Geografia e Estatística. Base de informações do Censo Demográfico 2010: resultados do universo por setor censitário. Rio de Janeiro: Instituto Brasileiro de Geografia e Estatística; 2011. 
29. Basta NE, Matthews FE, Chatfield MD, Brayne C. Community-level socio-economic status and cognitive and functional impairment in the older population. Eur J Public Health 2008; 18:48-54.

30. Al Hazzouri AZ, Haan MN, Osypuk T, Abdou C, Hinton L, Aiello AE. Neighborhood socioeconomic context and cognitive decline among older Mexican Americans: results from the Sacramento $\mathrm{Ar}$ ea Latino Study on Aging. Am J Epidemiol 2011; 174:423-31.

31. Sheffield KM, Peek MK. Neighborhood context and cognitive decline in older Mexican Americans: results from the Hispanic Established Populations for Epidemiologic Studies of the Elderly. Am J Epidemiol 2009; 169:1092-101.

32. Robert SA. Socioeconomic position and health: the independent contribution of community socioeconomic context. Annu Rev Sociol 1999; 25:489-516.

33. Wight RG, Aneshensel CS, Miller-Martinez D, Botticello AL, Cummings JR, Karlamangla AS, et al. Urban neighborhood context, educational attainment, and cognitive function among older adults. Am J Epidemiol 2006; 163:1071-8.

34. Garin N, Olaya B, Miret M, Ayuso-Mateos JL, Power $\mathrm{M}$, Bucciarelli P, et al. Built environment and elderly population health: a comprehensive literature review. Clin Pract Epidemiol Ment Health 2014; 10:103-15.

35. Foubert-Samier A, Le Goff $M$, Helmer C, Pérès $\mathrm{K}$, Orgogozo JM, Barberger-Gateau P, et al. Change in leisure and social activities and risk of dementia in elderly cohort. J Nutr Health Aging 2014; 18: 876-82.

36. Kobayashi LC, Wardle J, Wagner CV. Internet use, social engagement and health literacy decline during ageing in a longitudinal cohort of older English adults. J Epidemiol Community Health 2014; doi:10.1136/jech-2014-20473.

37. Ertel KA, Glymour MM, Berkman LF. Effects of social integration on preserving memory function in a nationally representative US elderly population. Am J Public Health 2008; 98:1215-20.
38. King D. Neighborhood and individual factors in activity in older adults: results from the neighborhood and senior health study. J Aging Phys Activ 2008; 16:144-70.

39. Kubzansky LD, Subramanian S, Kawachi I, Fay ME, Soobader MJ, Berkman LF. Neighborhood contextual influences on depressive symptoms in the elderly. Am J Epidemiol 2005; 162:253-60.

40. Secretaria de Vigilância em Saúde, Ministério da Saúde. Política Nacional de Promoção da Saúde. Brasília: Ministério da Saúde; 2006.

41. Malta DC, Silva MMA, Albuquerque GM, Lima CM, Cavalcante T, Jaime PC, et al. A implementação das prioridades da Política Nacional de Promoção da Saúde, um balanço, 2006 a 2014. Ciênc Saúde Coletiva 2014; 19:4301-12.

42. Brucki SM, Nitrini R, Caramelli P, Bertolucci PH Okamoto IH. Sugestões para o uso do mini-exame do estado mental no Brasil. Arq Neuropsiquiatr 2003; 61:777-81.

43. Lourenço RA, Veras RP. Mini-Exame do Estado Mental: características psicométricas em idosos ambulatoriais. Rev Saúde Pública 2006; 40:712-9.

44. Bertolucci PH, Brucki S, Campacci SR, Juliano Y. O mini-exame do estado mental em uma população geral: impacto da escolaridade. Arq Neuropsiquiatr 1994; 52:1-7.

45. Diex-Roux AV. Next steps in understanding the multilevel determinants of health. J Epidemiol Community Health 2008; 62:957-9.

46. Diex-Roux AV. Neighborhoods and health: where are we and where do we go from here? Rev Epidemiol Sante Publique 2007; 55:13-21.

47. Pickett KE, Pearl M. Multilevel analyses of neighbourhood socioeconomic context and health outcomes: a critical review. J Epidemiol Community Health 2001; 55:111-22. 


\section{Resumo}

O objetivo do estudo foi estimar a associação entre a renda contextual e o declínio cognitivo de idosos em Florianópolis, município de médio porte do Sul do Brasil. Realizou-se um estudo transversal aninhado numa coorte de idosos. Entrevistaram-se 1.197 indivíduos ( $\geq$ 60 anos) na segunda onda (2013/2014) da coorte EpiFloripa. O declínio cognitivo foi avaliado por meio do Mini Exame do Estado Mental (MEEM) e a renda contextual pelo rendimento médio mensal dos responsáveis pelos domicílios. As variáveis individuais de ajuste foram sexo, idade, cor da pele, renda domiciliar per capita, anos de estudos e tempo de moradia no bairro. Os dados foram analisados valendo-se de regressão logística multinível. A chance de declínio cognitivo foi duas vezes maior (OR =1,99; IC95\%: 1,03; 3,87) entre os idosos residentes nos setores do menor quintil de renda, quando comparados aos do maior quintil, independentemente das características individuais. Concluiuse que o ambiente socioeconômico está relacionado ao declínio cognitivo e deve ser considerado em políticas públicas com foco na promoção da saúde dos idosos.

Transtornos Cognitivos; Classe Social; Idoso

\section{Resumen}

El objetivo del estudio fue estimar la asociación entre la renta contextual y el declive cognitivo de ancianos en Florianópolis, municipio de tamaño medio del sur de Brasil. Se realizó un estudio transversal con una cohorte de ancianos. Se entrevistaron a 1.197 ancianos $(\geq 60$ años) en la segunda serie (2013/2014) de la cohorte EpiFloripa. El declive cognitivo se evaluó mediante un Mini Examen del Estado Mental (MEEM) y la renta contextual por el rendimiento medio mensual de los responsables de los domicilios. Las variables individuales de ajuste fueron sexo, edad, color de piel, renta domiciliaria per cápita, años de estudio y tiempo de residencia en el barrio. Los datos fueron analizados mediante regresión logística multinivel. La oportunidad de declive cognitivo fue dos veces mayor (OR = 1,99; IC95\%: 1,03; $3,87)$ en los ancianos residentes en los sectores de menor quintil de renta, cuando se comparan con los de mayor quintil, independiente de las características individuales. Se concluyó que el ambiente socioeconómico está relacionado con el declive cognitivo y debe ser considerado en políticas públicas centradas en la promoción de salud de los ancianos.

Trastornos del Conocimiento; Clase Social; Anciano
Submitted on $13 / \mathrm{Jul} / 2015$

Final version resubmitted on 22/Sep/2015

Approved on 15/Oct/2015 